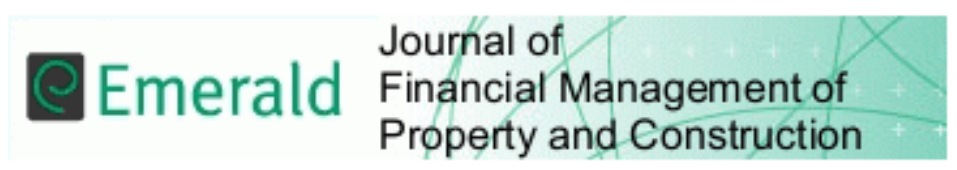

\title{
Obstacles to Comprehensive Real Estate Asset Management
}

\begin{tabular}{|r|l|}
\hline Journal: & Journal of Financial Management of Property and Construction \\
\hline Manuscript ID & JFMPC-05-2020-0036.R1 \\
\hline Manuscript Type: & Research Paper \\
\hline Keywords: & $\begin{array}{l}\text { Real Estate, Asset Management, Process Improvement, strategy, } \\
\text { Theories of the firm }\end{array}$ \\
\hline \multicolumn{2}{|l}{} \\
\hline
\end{tabular}




\section{Obstacles to Comprehensive Real Estate Asset Management}

Purpose: Motivated by behavioral theories of the firm, this study considers the extent to which knowledge gaps, organizational inertia, and conflicts of interest prevent large real estate investment management firms from approaching asset management in a comprehensive manner.

Design/methodology/approach: Results of 93 semi-structured interviews conducted with real estate practitioners in the United States are thematically analyzed.

Findings: All of the aforementioned factors are found to influence real estate asset management practices and serve as potential obstacles to operational excellence.

Originality: The study contributes to a small, but growing, body of research examining the challenges large real estate investment management firms face when trying to derive value from their asset management platforms.

Research limitations/implications: The qualitative analysis is limited in the sense that it focuses exclusively on the perceptions of real estate practitioners in the United States who work for relatively large organizations. However, it offers compelling evidence that comprehensive asset management is difficult under the best of circumstances, and becomes even more so in the presence of knowledge gaps, organizational inertia, and conflicts of interest.

Practical implications: Those working in asset management or with asset managers must be mindful of the obstacles discussed if they hope to encourage and facilitate process improvement.

Key Words: Real estate, asset management, strategy, process improvement, theories of the firm 


\section{Introduction}

A study recently published by the Institute of Real Estate Management ${ }^{\circledR}$ suggests that many large real estate investment management firms across the United States approach asset management in suboptimal ways (Read, 2019). Some of these approaches are described as analytical, others operational, and still others transactional, but what they all have in common is that they are purported to be inferior to more comprehensive approaches that focus on operational excellence, strategic decision-making, and long-term value creation. A question the study does not answer, however, is why comprehensive approaches to asset management are rare, while analytical, operational, and transactional approaches to asset management are not. Answering this question is important because it may help firms simultaneously use their human resources and financial resources more effectively achieve their property-level investment goals - an accomplishment that is ultimately what comprehensive asset management is all about.

Motivated by behavioral theories of the firm, the research presented in this manuscript probes the results of 93 semi-structured interviews conducted with real estate professionals to determine if knowledge gaps, organizational inertia, and conflicts of interest explain the apparent dearth of comprehensive asset management in practice. Each is found to be a contributing factor, with other contributing factors also coming into play. The findings complement the extant literature by shedding light on potential obstacles to comprehensive asset management that large real estate investment management firms must overcome to facilitate process improvement.

The remainder of the manuscript is organized as follows. Section 2 operationalizes real estate asset management and defines the four approaches previously identified. Section 3 offers plausible explanations as to why comprehensive asset management is uncommon despite the notable advantages it appears to offer. Section 4 describes the data and methodology used in this 
study to assess the merits of each of the explanations put forth. Section 5 summarizes the results of data analysis. Section 6 presents concluding remarks and an agenda for future research.

\section{Alternative Approaches to Asset Management}

Direct investments in income-producing real estate assets are management intensive (McAllister, 2012). Managerial input frequently comes in the form of portfolio management, asset management, and property management (Muczyński, 2015). Generally speaking, portfolio management focuses on deploying capital in a manner satisfying the risk and return requirements of a given group of real estate investors (Clayton et al., 2015); asset management focuses on achieving the financial goals established for each of the properties acquired (Glickman, 2004); and property management focuses on making day-to-day operational decisions, interfacing with tenants, and maintaining buildings within the confines of a budget (Goss and Campbell, 2008). These definitions are admittedly incomplete, but set the stage for more in-depth discussion.

Of the three management functions described, asset management is arguably the least well understood (Fields, 2015; Niebor, 2005). This is due in part to the limited availability of research on asset management as it pertains to properties held solely for investment purposes. Far more has been written about corporate and municipal real estate asset management - two related, yet distinct fields of study that respectively focus on helping private and public sector entities maximize the use value of their real estate holdings (Haynes et al., 2017; Kask, 2013; Lindholm et al., 2006; Scheffer et al., 2006; Wojewnik-Filipkowska and Rymarzak, 2013). These studies are interesting and informative, but do not speak directly to investors whose primary reason for acquiring real estate assets is to harvest the cash flow they are capable of generating. 
The paucity of research examining how sophisticated real estate investors approach asset management encouraged the Institute of Real Estate Management ${ }^{\circledR}$, a prominent real estate trade organization, to commission a study with the stated objective of defining asset management and differentiating it from property management. The end result was a book titled What Real Estate Asset Managers Do (Read, 2019). Consistent with the findings of a small number of related studies (e.g. Feldman, 1995; Jackson, 2012; McNair, 2010; Singh et al., 2012), the book concluded that asset management is a process involving several tasks, as presented in Figure 1.

\section{INSERT FIGURE 1 HERE}

Furthermore, the book found real estate investment management firms prioritize the aforementioned tasks in different ways - some of which are suboptimal - depending upon whether they view asset management as a process centered on financial management or as a process centered on human resource management. This observation led to the development of the typology presented in Figure 2, which describes analytical, operational, transactional, and comprehensive approaches to asset management to which many firms orient.

\section{INSERT FIGURE 2. HERE}

Firms with analytical orientations conceptualize asset management as more of a financial management activity than a human resource management activity. Considerable time is spent looking for trends and anomalies in data that may serve as evidence that property-level business plans are on track or in need of refinement. Motivating property managers and leasing personnel, as well as others involved in the asset management process, is secondary to providing them with actionable information and measuring their progress toward defined goals. Analytical asset managers rely heavily on key performance indicators and other metrics when making decisions. 
In sharp contrast, firms with operational orientations conceptualize asset management as more of a human resource management activity than a financial management activity. Close collaboration between asset management and property management teams is the norm, with parties working in both camps possessing a deep understanding of real estate as a physical asset that must be maintained and competitively positioned. Information derived from site visits and market tours is often given more weight than that derived from economic and financial models. Operational efficiency and tenant satisfaction are at the heart of asset management strategies.

Firms with transactional orientations do not conceptualize asset management as an oversight task or as an extension of property management. Rather, they believe the best way to add value is by driving revenue growth through aggressive leasing and marketing activities. Thus, individuals working in asset management systematically look for strengths and weaknesses in rent rolls and proactively take steps to enhance the mix of tenants in their portfolios. They involve themselves in lease negotiation early on and leverage relationships with the brokerage community. Analytical and operational responsibilities are liberally delegated to others to free asset management personnel to source and close deals in collaboration with leasing teams.

Comprehensive asset management focuses on the interplay between all of the activities discussed thus far. Firms with this type of orientation employ asset managers who have a thorough understanding of financial management, yet they do not call on these individuals to engage in an extensive amount of financial modeling. Instead, they surround asset managers with resources so they can spend the bulk of their time thoughtfully coordinating the implementation of property-level business plans. These firms expect their asset managers to clearly communicate their goals to property managers and leasing agents, without becoming entrenched in day-to-day operations or leasing decisions unless absolutely necessary. Furthermore, they charge asset 
managers with understanding the unique competitive advantages of each of the properties in their portfolios and the factors that can erode competitive advantages if left unchecked.

\section{Potential Obstacles to Comprehensive Asset Management}

Although the terms analytical, operational, transactional, and comprehensive asset management are new to the real estate lexicon, the idea that real estate investment management firms should aspire to the latter is not. The work of Andonov et al. (2013), McAllister (2020), Muczyński (2015), Palm (2013), and Poon and Brownlow (2014), among others, suggests that intensifying market competition is putting pressure on such firms to have highly-specialized, yet well-integrated, management functions that accommodate strategic decision-making and longterm value creation. This is the very nature of comprehensive asset management because it focuses on the collaborative development and implementation of plans capable of maximizing the value of income-producing properties from the time of purchase until the time of sale. In light of widespread recognition of the benefits comprehensive asset management can yield, evidence that it is more the exception than the rule in the United States is rather surprising (Read, 2019). The finding begs the question of why comprehensive asset management is relatively rare.

Figure 3 presents three plausible explanations for this phenomenon, the first of which relates to the nascent state of the of the real estate investment management industry overall. Only in the last four decades have portfolio management, asset management, and property management evolved into the sophisticated enterprises known today (Clayton et al., 2009; Glickman, 2004; Goss and Campbell, 2009; Read et al., 2016). To the extent many real estate investment management firms are still learning how best to approach and coordinate these activities, knowledge gaps may stand in the way of comprehensive asset management. 


\section{INSERT FIGURE 3 HERE}

Organizational inertia may also explain why real estate investment management firms stick with analytical, operational, and transactional approaches to asset management despite the advantages comprehensive asset management appears to offer. Research carried out over the last half century demonstrates that firms operating in an array of industries are often slow to modify their business models in response to changing market conditions, which tends to make them less competitive over time (Amabile et al., 1996; Hannan and Freeman, 1977; Huang et al., 2013). The threat of complacency may extend to real estate investment management firms (Palm, 2013).

Conflicts of interest are a third potential obstacle to comprehensive asset management. Individuals working in portfolio, asset, and property management often have different priorities (Grenadier and Wang, 2005; Klingenberg and Brown, 2006; Park, 2017). For example, this may be the case when property managers are rewarded for increasing net rental revenues, asset managers for increasing net operating income, and portfolio managers for increasing fees based on the value of assets under management (Hoesli and Oikarinen, 2016; Read et al., 2016; Sirmans et al., 1999). Poorly aligned incentives discourage cooperation, making comprehensive asset management difficult, if not impossible, in the absence of intervening factors.

Although knowledge gaps, organizational inertia, and conflicts of interest are distinct and separate concerns, they are linked together by behavioral theories of the firm tracing their roots to the influential work of Cyert and March (1963). Behavioral theories differ from more traditional neoclassical economic theories by rejecting the assumption that firms possess perfect information and act in a unitary manner to maximize profits (Seth and Howard, 1994).

Alternatively, firms are conceptualized as collections of individuals with different motivations and priorities who must make decisions in the face of uncertainty (Argote and Greve, 2007). 
These conditions are anticipated to lead to intra-organizational tensions and satisficing behaviors that stand in the way of operational efficiency (Suzuki, 2008). For example, they may impede knowledge diffusion, inhibit organizational change, and encourage managers with limited time and cognitive capacity to seek out solutions to problems that yield acceptable outcomes as opposed to optimal outcomes (Barnett and Potikes, 2008; Roome and Wijen, 2005). Since there is no reason to believe large real estate investment management firms are more resilient to these threats than others types of organizational, there is great value in using behavioral theories to better understand obstacles to comprehensive asset management that may exist in practice.

\section{Data and Methodology}

Knowledge gaps, organizational inertia, and conflicts of interest are all plausible explanations for why many real estate investment management firms across the United States fall short of comprehensive asset management. However, the merits of these explanations have not yet been rigorously evaluated. This study seeks to fill the void in the real estate literature.

After using trade journal rankings to compile a list of 257 of the largest real estate investors and service providers in the United States, each of these firms was asked to participate in a research project examining common asset management practices across the country. Representatives of 93 of these firms ultimately agreed to be interviewed. All of the interviewees worked in asset management or with asset managers despite representing many different types of organizations including life insurance companies, owner-operators, private equity funds, publicly-traded REITs, and third-party real estate service providers, among others. The firms included in the sample work on behalf of owners of regional, national, or international real estate portfolios ranging in size from a few hundred million dollars to several billion dollars. Some portfolios are comprised of a single real estate product type and others multiple product types. 
The interviews were conducted in 2016, with some research participants contacted in 2017 and 2018 to respond to follow-up questions. Non-probabilistic sampling was used to ensure interviewees had sufficient knowledge of the topic of interest (Gibson and Barkham, 2001). A sample comprised of individuals working for different types of organizations with different job titles was not deemed problematic due to the expertise interviewees possessed (Harvey, 2011). Telephone interviews were chosen over in-person interviews because they offer a reliable means of collecting data from real estate professionals working in different areas (Hopkins et al., 2017). Semi-structured interviews were selected to give research participants flexibility to discuss issues they deemed most important (Levy and Lee, 2009; Palm, 2013). Adhering to best practice, openended prompt questions guiding the interviews were pretested and provided to the research participants for review in advance (Read and Sanderford, 2018; Read and Carswell, 2019).

Directly relevant to the research at hand, interviewees were asked to operationalize asset management, differentiate it from portfolio and property management, and describe how it is conducted in their firms or in the firms with which they work. These questions served as a means of encouraging interviewees to discuss asset management within the context of overarching management hierarchies, which was essential to evaluate the pervasiveness of intraorganizational tensions and conflicts of interest. Interviews were also asked to discuss inefficiencies in existing asset management processes and barriers to process improvement. In addition to accommodating an assessment of whether knowledge gaps and organizational inertia were perceived to be problems, these questions allowed for an examination of how such problems affect asset management practices and decision-making processes. Answers to all of the prompt questions were reviewed and manually coded to identify recurrent themes. Following 
the work of Read et al. (2019), a priori and emergent coding methodologies were used because some themes were predetermined, whereas others emerged during data collection.

\section{Results}

Subthemes related to knowledge gaps, organizational inertia, and conflicts of interest are discussed first to ground the manuscript in the existing real estate literature. Attention is then turned to themes unanticipated at the outset of the research. In both cases, comments made by interviewees are incorporated into the discussion to highlight key points.

\subsection{Evidence of Knowledge Gaps}

Some interviewees spoke of well-developed asset management platforms, fully satisfying the needs of their firms. Over half, however, spoke of areas in need of improvement. Problems commonly cited by the latter group included inadequate asset management processes; uncertainty as to how asset management should be integrated into the broader organizational structures of real estate investment management firms; concerns about the amount of power and autonomy asset management personnel should be granted in the ordinary course of business; and a lack of clarity as to how aspirant asset managers should be trained. All of these problems serve as evidence of knowledge gaps that may stand in the way of comprehensive asset management.

Approximately $20 \%$ of the interviewees openly acknowledged that their firms have not yet mastered asset management. Perhaps more surprisingly, members of this group frequently went on to state that they do not have a clear plan in place for improvement. As one asset manager working for an insurance company said: "Asset management is evolving in our company. We have a sense of what we want the process to look like, but we aren't there yet. There is a lot of uncertainty about what works and about what our competitors are doing." Other 
interviewees similarly described their firms' asset management processes as "incomplete," "poorly built out," and "more fluid than we would like."

As a general rule, improving the execution of discrete asset management tasks was not

Among interviewees working for firms that recently reorganized their management structures, there were those who said their firms combined asset management departments with acquisitions departments, leasing departments, or property management departments to “empower," "encourage," and "incentivize" individuals to collaborate more effectively, while there were also those who said their firms decoupled these departments to achieve exactly the same end. In all of these cases, interviewees lamented the fact that best practices guiding such decisions are rare. “As an organization, we've struggled to get as much value out of asset management as we should," said an asset manager working for an owner-operator, "We keep trying different things and would love to know what others are doing."

Uncertainty about how to derive maximum value from asset management processes and personnel extended to issues of power and autonomy. Interviewees expressed very different opinions about the role asset managers should play within the organizations they represent. An asset manager working on behalf of a publicly-traded REIT emphasized the point by stating: "There are companies that think everyone who touches a property should report to the asset manager; there are companies that think asset managers should act as advisors and nobody 
should report to them; and there are companies that fall somewhere in between. It's hard to tell who is doing it right." The comment suggests that the amount of professional discretion afforded to asset managers varies greatly across firms, offering little indication of accepted best practice.

A final knowledge gap relates to uncertainty as to how firms should train asset managers. “Asset management requires a unique skillset," said an interviewee working in private equity, "How do you teach someone to be creative? To delegate effectively? To deal with uncertainty?" Echoing the sentiments of others, the interviewee went on to state that many real estate investment management firms do not approach asset management exactly the way they want to because they have difficulty developing these skills in their mid-level management personnel.

\subsection{Evidence of Organizational Inertia}

The aforementioned knowledge gaps are unsurprising in light of asset management's relatively short history. More troubling is evidence of organizational inertia. Only five interviewees directly stated that their firms are resistant to change, but five times that number made comments suggesting this is the case. These comments relate to the way real estate investment management firms rationalize approaches to asset management and make outsourcing decisions, as well as the way they staff asset management departments and allocate resources.

When asked to explain why their firms engage in asset management the way they do, common responses were derivatives of "it is the way we have always done things," "it is how our company has evolved," and "it is consistent with our corporate culture." Rarely were these explanations accompanied by any discussion of systematic efforts on the part of firms to evaluate the efficacy of their existing asset management practices. Furthermore, the most frequently cited catalysts for change were external forces such as competitive pressures and client demands, as 
opposed to internal pressures to improve asset management processes. Interviewees who admitted their firms are more reactive than proactive often laid blame at the feet of their superiors. "We'd like to be more proactive," said an asset manager working for an insurance company, "But senior leadership defines the priorities, and the priorities define the way we approach asset management. Asset management only changes when the priorities change."

The strongest evidence of organizational inertia emerged in answers to questions about property management and leasing. Interviewees whose firms outsource these services typically advocated for such an approach and contended that it keeps asset managers focused on long-term investment objectives rather than short-term operational objectives. Alternatively, interviewees whose firms handle property management and leasing internally tended to believe it provides asset managers with better intelligence about the properties in their portfolios, the needs of the tenants who occupy them, and the dynamics of the markets in which they are located. Neither group of interviewees could put forth quantitative support for their positions, quickly turning to anecdotal evidence to justify entrenched property management and leasing strategies.

Real estate investment management firms were also reported to be reluctant to critically evaluate how they staff asset management departments. An executive recruiter specializing in asset and property management described the problem: "In my experience, companies think of asset managers as real estate professionals with lots of quantitative horsepower or as real estate professionals with lots of operational experience. Sure, they would love to have both, but those people are hard to find, so they generally end up with one skillset or the other. The one they pick dictates how they go about asset management because asset managers play to their strengths." Asset managers with backgrounds in operations and leasing were posited to have great difficulty “staying out of the weeds," just as asset managers with financial service backgrounds were 
posited to have great difficulty viewing real estate as "more than numbers in a spreadsheet." These comments clearly illustrate that staffing decisions can perpetuate existing approaches to asset management that are analytical, operational or transactional, rather than comprehensive.

As one might expect, providing asset management departments with insufficient resources was perceived to stymie positive change just as much as poor staffing decisions. "You can talk about strategy and long-term planning all you want, but if asset managers don't have the support they need they are going to be reactive, not proactive. They can't think about creating value until they have all of the basics covered and they can't cover the basics without help." Failing to surround experienced asset managers with financial analysts and junior personnel was thought not only to encourage asset management processes to be static, but also to create a very real risk of asset management devolving into little more than a reporting activity.

\subsection{Evidence of Conflicts of Interest}

Recognizing organizational inertia is one thing; overcoming conflicts of interest that stand in the way of positive organizational change is another. Interviewees made this clear by speaking extensively about intra-organizational tensions and poorly aligned incentives that prevent asset management personnel from working effectively with property managers, leasing agents, and acquisition specialists, not to mention members of senior leadership teams.

While research participants uniformly agreed that asset managers and property managers must work together to push rents and control operating expenses, they did not uniformly agree that this is easy. Tension was reported to exist both in firms that outsource property management services and those that insource. "Even when property managers work for your company, they don't tell you the whole truth," said one asset manager representing an owner-operator, "They 
are concerned about hitting the budget and maintaining the property in a way that minimizes the day-to-day management burden, not necessarily in maximizing the owner's return on investment. They only communicate the information that advances their interests unless you compel them to provide more." An asset manager representing a private equity firm expressed similar concerns, adding that relationships with third-party property management companies are even more complicated: "The property management companies we work with are trying to drive up their profit margins and we are trying to drive them down. As a result, asset managers spend more time holding property managers accountable than they do collaborating with them."

Asset managers' goals and leasing agents' goals were also thought to be incongruent in some instances, but for different reasons. An interviewee representing a publicly-traded REIT described the problem in the following way: "Leasing agents have a very different mindset than asset managers. They want to get deals done and get paid and they aren't always thinking about the long-term impact of those deals on the property. Asset managers try to box them in by communicating acceptable credit and lease terms, but it takes time and often requires them to be more involved in prospecting and lease negotiations than they might otherwise prefer."

Relationships between asset managers and acquisition specialists were thought to be no less complex. "Acquisition guys and asset management guys need each other, but they are fundamentally different animals and have different incentives," said an interviewee representing an insurance company, "The acquisition guys are motivated to get properties bought and the asset management guys are motivated to make sure properties can perform to the underwriting. Tensions arise between the two groups and they can be good or bad depending on how they are managed." Interviewees expressed uncertainty about how to manage such tensions, while still keeping asset managers involved in property-level business planning. 
Reward systems put in place by senior management were another potential source of intra-organizational conflict commonly cited by interviewees. "Lots of asset management successes get overlooked," said an asset manager working for an insurance company, "No one acknowledges you for improving channels of communication, keeping everyone focused on the same goals, or resolving issues before they become problems. All of that stuff is important, but it isn't visible and it isn't rewarded." Asset managers unable to gain recognition for these activities were said to have little incentive to approach their work in a comprehensive or holistic manner.

\subsection{Evidence of Other Obstacles to Comprehensive Asset Management}

Three recurrent themes observed in the data could not easily be explained as products of knowledge gaps, organizational inertia, or conflicts of interest. The first relates to market cycles, the second technology adoption, and the third divergent perspectives as to how budgets should inform asset management decisions. Each offers additional insight about approaches to asset management commonly observed in the real estate investment management industry.

A dozen interviewees noted that the priorities of asset managers change across real estate market cycles. "We focus on supporting development, acquisitions, and leasing when there are deals to be done and on managing risk and controlling costs when there aren't deals to be done" said an asset manager working for an owner-operator, "We should be focusing on all of these things all of the time, but there are only so many hours in the day." Another asset manager working for a private equity fund similarly stated: "The properties you already own and the tenants you already have always get less attention when the market is good. People usually don't start thinking about tenant satisfaction and asset preservation until the market gets soft." Both of these interviewees admitted that such an approach is shortsighted, but nonetheless common. 
Statements made by interviewees also suggest comprehensive asset management is closely linked to technology adoption. Interviewees satisfied with IT systems within their own firms were frequently more satisfied with their asset management processes and more confident that they add value than were those unsatisfied with their IT systems. "Putting systems in place that make it easier for asset managers to share data with others and with one another has completely changed the way we do business," said an asset manager representing a publiclytraded REIT, “Asset managers aren't spending all of their time making or responding to requests for data. They are using data as a tool to make more informed decisions and helping others do so as well." Conversely, interviewees working for firms with less well developed IT platforms often expressed frustration that much of their time is spent managing data, or figuring out what data to collect, rather than putting that data to productive use.

Views about budgeting are a final potential obstacle to comprehensive asset management unanticipated at the outset of the research. Asset managers working for every type of firm represented in the sample bemoaned the amount of time spent revising cash flow projections. However, a more significant problem in the minds of many interviewees was a tendency on the part of some portfolio managers to view operating and capital budgets as documents demanding strict adherence, as opposed to simply planning instruments. An asset manager's ability to business plan in a dynamic and market responsive way was said to hinge on portfolio managers' willingness to consider leases and capital improvement projects that are in line with the market, yet in conflict with the underwriting assumptions made at the time a property was acquired or at the beginning of a year. "Budgets are important," said an interviewee working for a third-party service provider, "But, companies often make bad decisions when they over-rely on projections made in the past. Sometimes you just have to sign the best lease available or spend some 
additional money to make your property more competitive regardless of what the budget says." Asset managers without such discretion were said to have difficulty doing their jobs well.

\section{Concluding Remarks}

The qualitative analysis presented in this manuscript is limited in the sense that if focuses exclusively on the perceptions of real estate practitioners in the United States who work for relatively large organizations. However, it offers compelling evidence that comprehensive asset management is difficult under the best of circumstances, and becomes even more so in the presence of knowledge gaps, organizational inertia, and conflicts of interest. These findings are unsurprising on their face, but contribute to the real estate literature nonetheless by suggesting that behavioral theories of the firm, as introduced by Cyert and March (1963) and expanded upon by many others, offer useful lenses through which to examine the decision-making processes and operating procedures of large real estate investment management firms. This is a promising line of research likely to complement the work of other real estate scholars interested in helping such firms develop effective asset management strategies (McAllister, 2020; Park, 2017; Read, 2019).

Three research questions are of particular interest. First - How do real estate investment management firms promote organizational learning to ensure those involved in asset management activities share knowledge and embrace best practices? Second - What strategies can real estate investment management firms adopt to avoid complacency among their asset management personnel that may stand in the way of their professional goals? Third - To what extent can real estate investment management firms mitigate intra-organizational conflicts of interest by changing management hierarchies, corporate cultures, and incentive systems that affect the way they approach asset management? Answering these questions may help firms move toward comprehensive asset management should they deem it advantageous to do so. 
There are also opportunities to consider the extent to which the lessons learned from this research apply to and other professional disciplines. It stands to reason that many of the obstacles to process improvement observed in the asset management space may extend to other segments of the real estate industry. Determining whether or not this is the case may lay the groundwork for improved operational processes and procedures in a diverse array of firms.

\section{References}

Argote, L., and Greve, H. R. (2007). A behavioral theory of the firm - 40 years and counting: Introduction and impact. Organizational Science, 18(3), 337-349.

Amabile, T.M., Conti, R., Coon, H., Lazenby, J., and Herron, M. (1996). Assessing the work environment for creativity. Academy of Management Journal, 39(5), 11541184.

Andonov, A., Kok, N. and Eichholtz, P. (2013). A global perspective on pension fund investments in real estate. The Journal of Portfolio Management, Special Real Estate Issue, 32-42.

Barnett, W.P., and Pontikes, E.G. (2008). The Red Queen, success bias, and organizational inertia. Management Science, 54(7), 1237-1251.

Clayton, J., Fabozzi, F. J., Giliberto, S. M., Gordon, J. N., Liang, Y., MacKinnon, G., and Mansour, A. (2015). New Horizons and Familiar Landscapes: New Capital Sources Confront Shifting Real Estate Fundamentals. The Journal of Portfolio Management, 41(5), 11-20.

Cyert, R.M., and March, J.G. (1963). A behavioral theory of the firm. Englewood Cliffs, NJ: Prentice Hall. 
Feldman, D.S. (1995). Asset management here to stay. Cornell Hotel and Restaurant Administration Quarterly, 36(5), 36-51.

Fields, T.J. (2015), Blurred lines, redefined. Journal of Property Management, 80(1), 42-46.

Gibson, V.A., and Barkham, R. (2001). Corporate management in the retail sector. Journal of Real Estate Research, 22(1/2), 107-127.

Glickman, I.H. (2004), The ABCs of asset management. Real Estate Issues, 29(3), 7-12.

Goss, R. C., and Campbell, H. L. (2008). The evolution of residential property management: From caretaker to income maximization managers. Housing and Society, 3(1), 5-20.

Grenadier, S.R., and Wang, N. (2005). Investment timing, agency, and information. Journal of Financial Economics, 75, 493-533.

Hannan, M.T., and Freeman, J. (1977). The population ecology of organizations. American Journal of Sociology, 82(5), 929-964.

Harvey, W. S. (2011), Strategies for conducting elite interviews. Qualitative Research, 11(4), 431-441.

Haynes, B., Nunnington, N., and Eccles, T. (2017). Corporate real estate asset management: Strategy and implementation. Second Edition. New York, NY: Routledge.

Hoesli, M., and Oikarinen, E. (2016). Are public and private asset returns and risks the same? Evidence from real estate data. The Journal of Real Estate Portfolio Management, 22(2), 179-198. 
Hopkins, E., Read, D.C., and Goss, R.C. (2017), Promoting sustainability in the United States multifamily property management industry. Journal of Housing and the Built Environment, 32(2), 361-376.

Huang, H.C., Lai, M.C., Lin, L.H., and Chen, C.T. (2013). Overcoming organizational inertia to strengthen business model innovation: An open innovation perspective. Journal of Organizational Change Management, 26(6), 977-1002.

Jackson, L.A. (2012). Towards an understanding of lodging asset management and its components. Hospitality Review, 30(1), 92-110.

Kask, K. (2013). Public sector real estate asset management models and their financial evaluation (Doctoral dissertation, University of Tartu, Tartu, Estonia). Retrieved from https://web-proxy.io/proxy/dspace.ut.ee/bitstream/handle/10062/44336/kask_kaia.pdf

Klingenberg, B., and Brown, R.J. (2006). Optimization of residential property management. Property Management, 24(4), 397-414.

Levy, D., and Lee, C. (2009), Switching behavior in property related professional services, Journal of Property Research. 26(1), 87-103.

Lindholm, A.L., Gibler, K.M., and Leväinen, K.I. (2006). Modeling the value-adding attributes of real estate to the wealth maximization of the firm. Journal of Real Estate Research, 28(4), 445-475.

MacNair, G.E. (2010). Creating value with strategic asset management. Right of Way, July/August, 40-44. 
McAllister, P. (2020). Creating operational alpha? Operating models for real estate management. Property Management, 38(4), 565-583.

McAllister, P. (2012). Viewpoint: Why do research on commercial property management? Somebody HAS to! Property Management, 30(1), 1-6.

Muczyński, A. (2015), An integrated approach to real estate (portfolio) management, Real Estate Management and Valuation, 23(2), 5-16.

Nieboer, N. (2005). How strategic is housing asset management of institutional real estate investors? Property Management, 23(1), 22-32.

Palm, P. (2013), Strategies in real estate management: Two strategic pathways. Property Management, 31(4), 311-325.

Park, Y.W. (2017). An exploratory study of agency costs of sponsored REITs in Singapore, Hong Kong, and Japan. The Journal of Real Estate Portfolio Management, 23(1), 35-50.

Poon, J., and Brownlow, M. (2014). Competency expectations for property professionals in Australia. Journal of Property Investment \& Finance, 32(3), 256-281.

Read, D.C. (2019). What real estate asset managers do. Institute of Real Estate Management: Chicago, IL.

Read, D.C., and Carswell, A. (2019). Is property management viewed as a valued-added service? Property Management, 37(2), 262-274.

Read, D., Fisher, P., and Juran, L. (2019). How do women maximize the value of mentorship? Leadership \& Organizational Development Journal. https://doi.org/10.1108/LODJ-022019-0094. 
Read, D.C., Hopkins, E. and Goss, R.C. (2016). Working effectively with asset managers and institutional groups. Property Management, 34(4), 280-296.

Read, D.C., and Sanderford, A. (2018). Sustaining sustainability in large real estate investment management firms. Journal of Real Estate Portfolio Management, 24(1), 19-33.

Roome, N., and Wijen, F. (2005). Stakeholder power and organizational learning in corporate environment management. Organization Studies, 27(2), 235-263.

Scheffer, J.J.L., Singer, B.P. and Van Meerwijk, M.C.C. (2006). Enhancing the contribution of corporate real estate to corporate strategy. Journal of Corporate Real Estate, 8(4), 188197.

Singh, A.J., Kline, R.D., Qingzhong, M., and Beals, P. (2012). Evolution of hotel asset management: The historical context and current profile of the profession. Cornell Hospitality Quarterly, 53(4) 326-338.

Sirmans, S.G., Sirmans, C.F., and Turnbull, G.K. (1999). Prices, incentives and choice of management form. Regional Science and Urban Economics, 29(2), 173-196.

Suzuki, O. (2013). Organizational slack, structure, and learning: A review of prior literature. Social Science Review, 18, 81-99.

Wojewnik-Filipkowska, A., and Rymarzak, M. (2013). Decision-making in corporate and municipal asset management: A literature review. International Journal of Real Estate Studies, 8(1), 16-29. 


\section{Figure 1. Real Estate Asset Management Tasks}

\begin{tabular}{|c|c|}
\hline $\begin{array}{l}\text { Acquisition } \\
\text { Support: }\end{array}$ & $\begin{array}{l}\text { Acquisition specialists frequently call on asset managers to vet underwriting } \\
\text { assumptions and assess the strengths and weaknesses of properties before } \\
\text { moving forward with purchase agreements. In some firms, asset managers are } \\
\text { also asked to help source deals and oversee due diligence activities. }\end{array}$ \\
\hline $\begin{array}{l}\text { Business } \\
\text { Planning: }\end{array}$ & $\begin{array}{l}\text { Business plans are often developed when properties are acquired, but must be } \\
\text { revised over time. It typically falls to asset managers to ensure such plans } \\
\text { reflect the physical condition properties are in, the strength of their rent rolls, } \\
\text { and the dynamics of the markets and submarkets in which they are located. }\end{array}$ \\
\hline $\begin{array}{l}\text { Leading a } \\
\text { Team: }\end{array}$ & $\begin{array}{l}\text { Property managers, leasing agents, construction managers, and a host of other } \\
\text { parties must work together to execute property-level business plans. Asset } \\
\text { managers lead or oversee the work of these parties in many instances. }\end{array}$ \\
\hline $\begin{array}{l}\text { Budget } \\
\text { Preparation: }\end{array}$ & $\begin{array}{l}\text { While property managers frequently prepare budgets, asset managers may be } \\
\text { called on to evaluate, refine, and approve them on behalf of the real estate } \\
\text { owners they represent. The final product represents the allocation of resources } \\
\text { to achieve the goals articulated in property-level business plans. }\end{array}$ \\
\hline $\begin{array}{l}\text { Approving Leases and } \\
\text { Capital Improvements: }\end{array}$ & $\begin{array}{l}\text { The amount of autonomy asset managers possess varies greatly across firms, } \\
\text { but it is common for individuals working in this capacity to have authority to } \\
\text { approve leases and capital expenditure decisions up to defined limits. }\end{array}$ \\
\hline $\begin{array}{l}\text { Promoting } \\
\text { Operational Efficiency: }\end{array}$ & $\begin{array}{l}\text { Benchmarking operational performance, looking for anomalies in data, and } \\
\text { seeking out cost savings opportunities in conjunction with property } \\
\text { management teams are all activities in which asset managers engage. }\end{array}$ \\
\hline $\begin{array}{l}\text { Financial } \\
\text { Analysis: }\end{array}$ & $\begin{array}{l}\text { Achieving the financial goals established for properties and maximizing their } \\
\text { value are fundamental responsibilities of asset managers, which require an } \\
\text { understanding of common real estate valuation techniques and alternative } \\
\text { measures of return on investment. }\end{array}$ \\
\hline $\begin{array}{l}\text { Market } \\
\text { Analysis: }\end{array}$ & $\begin{array}{l}\text { Market analysis informs all other asset management activities. It helps asset } \\
\text { managers understand how properties are performing, what types of lease } \\
\text { terms are acceptable in light of market conditions, and how capital } \\
\text { investments can help differentiate properties from their competitors. }\end{array}$ \\
\hline $\begin{array}{l}\text { Disposition } \\
\text { Assistance: }\end{array}$ & $\begin{array}{l}\text { Many real estate investment management firms opportunistically sell } \\
\text { properties. Asset managers help them determine when it is appropriate to do } \\
\text { so by making hold/sell recommendations, and in some instances by working } \\
\text { with the brokerage community to complete sale transactions. }\end{array}$ \\
\hline $\begin{array}{l}\text { Monitoring and } \\
\text { Reporting: }\end{array}$ & $\begin{array}{l}\text { Asset managers inform the real estate owners they represent in a number of } \\
\text { ways. They engage in financial reporting, communicate capital needs, explain } \\
\text { budget variances, evaluate market conditions, and assess competitive threats, } \\
\text { all while being mindful of short- and long-range investment objectives. }\end{array}$ \\
\hline
\end{tabular}

Figure adapted from Read (2019) 
Figure 2. Real Estate Asset Management Typology

\begin{tabular}{|c|c|c|}
\hline & $\begin{array}{c}\text { Strong } \\
\text { Human Resource Management } \\
\text { Orientation }\end{array}$ & $\begin{array}{c}\text { Moderate } \\
\text { Human Resource Management } \\
\text { Orientation }\end{array}$ \\
\hline $\begin{array}{l}\text { Strong } \\
\text { Financial Management } \\
\text { Orientation }\end{array}$ & $\begin{array}{l}\text { Comprehensive Asset Management } \\
\text { Asset management is much more } \\
\text { than data analysis or an extension of } \\
\text { property management and leasing } \\
\text { activities. It is a strategic and well- } \\
\text { coordinated process focused on } \\
\text { value creation and cash flow } \\
\text { maximization. Asset management } \\
\text { personnel achieve these goals by } \\
\text { communicating business plans to } \\
\text { interdisciplinary teams, motivating } \\
\text { them to achieve the objectives } \\
\text { defined therein, and making data- } \\
\text { driven decisions. }\end{array}$ & $\begin{array}{l}\text { Analvtical Asset Management } \\
\text { Asset management is a quantitative } \\
\text { endeavor. Financial modeling, } \\
\text { revenue and expense forecasting, and } \\
\text { trend analysis consume an extensive } \\
\text { amount of asset managers' time, often } \\
\text { supplanting site visits and tenant } \\
\text { interactions in importance. Great } \\
\text { value is perceived to stem from } \\
\text { dispassionately evaluating properties } \\
\text { through the numbers and making } \\
\text { decisions accordingly. Motivating } \\
\text { teams and communicating a vision are } \\
\text { often secondary considerations. }\end{array}$ \\
\hline $\begin{array}{l}\text { Moderate } \\
\text { Financial Management } \\
\text { Orientation }\end{array}$ & $\begin{array}{l}\text { Operational Asset Management } \\
\text { Asset management is closely akin to } \\
\text { property management, with those } \\
\text { responsible for the former often } \\
\text { having extensive experience in the } \\
\text { latter. Promoting operational } \\
\text { efficiency and ensuring tenant } \\
\text { satisfaction are key priorities, and as } \\
\text { such, more attention is devoted to } \\
\text { things happening onsite than offsite. } \\
\text { Information derived from financial } \\
\text { models is given less credence than } \\
\text { information derived from human } \\
\text { interactions. }\end{array}$ & $\begin{array}{l}\text { Transactional Asset Management } \\
\text { Asset management is largely about } \\
\text { driving top-line revenue growth, } \\
\text { leading personnel working in this } \\
\text { space to spend a significant amount of } \\
\text { their time engaged in lease } \\
\text { negotiations and marketing activities. } \\
\text { Other tasks are liberally delegated to } \\
\text { make this possible. Asset managers } \\
\text { are extremely familiar with the } \\
\text { markets in which they operate and } \\
\text { have extensive networks they can } \\
\text { leverage to improve the rent rolls of } \\
\text { the properties under their supervision. }\end{array}$ \\
\hline
\end{tabular}

Figure adapted from Read (2019) 
Figure 3. Potential Obstacles to Comprehensive Real Estate Asset Management

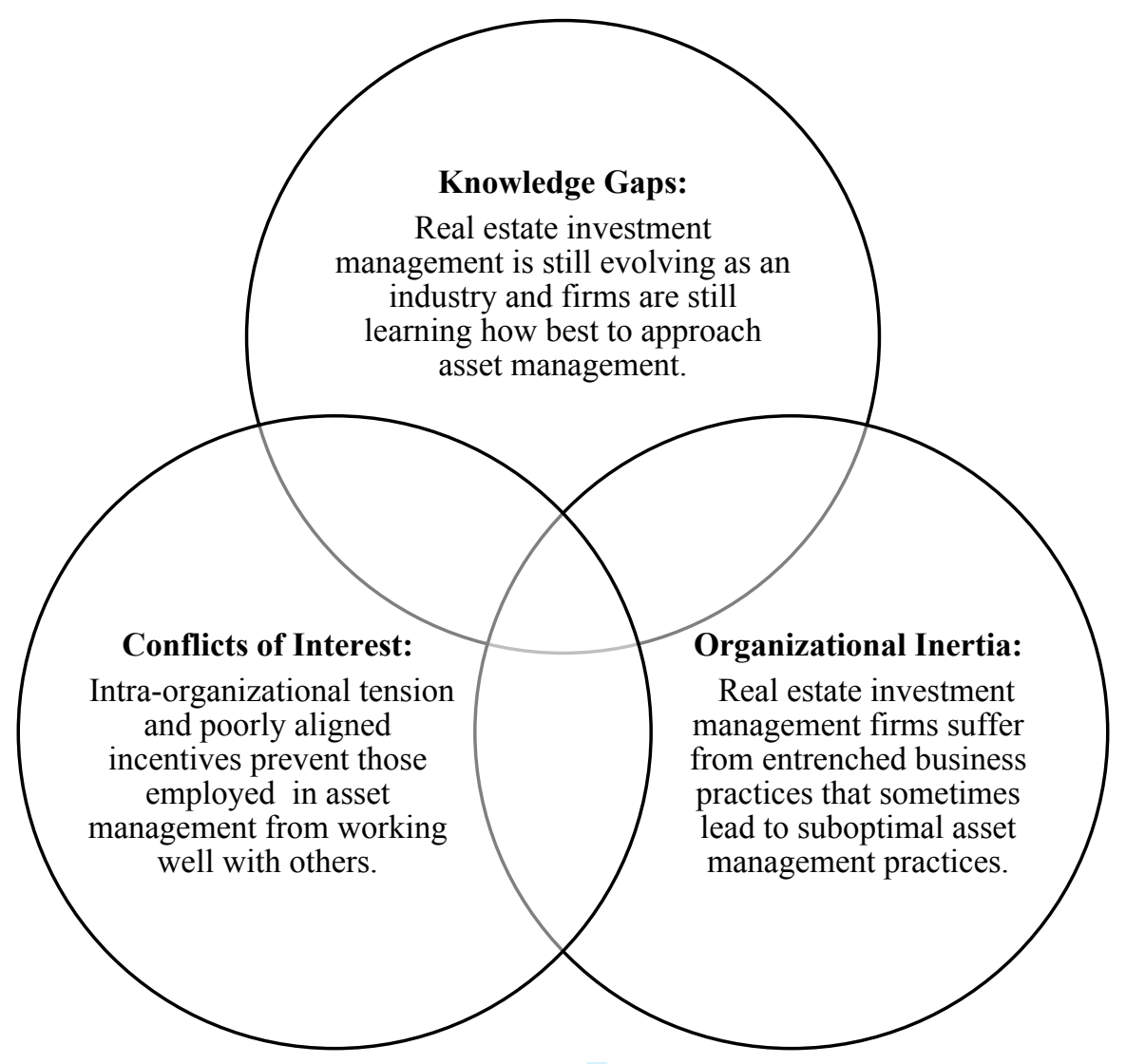




\title{
The Journal of Financial Management of Property and Construction Author(s') Response to Reviewers Form
}

\author{
Manuscript ID: JFMPC-05-2020-0036
}

\begin{tabular}{|c|c|}
\hline \multicolumn{2}{|c|}{ Referee 1} \\
\hline $\begin{array}{l}\text { Within the literature review the author refers to } \\
\text { "current literature not covering comprehensive asset } \\
\text { management". It would be helpful, but not essential, } \\
\text { to have this statement expanded on as to what is } \\
\text { considered "comprehensive" }\end{array}$ & $\begin{array}{l}\text { The referee very appropriately points out that } \\
\text { comprehensive asset management needs to be } \\
\text { defined in some way earlier in the manuscript. } \\
\text { Rather than revising the literature review, where } \\
\text { comprehensive asset management is already defined } \\
\text { on p. } 5 \text { and again in Figure } 2 \text {, we revised the opening } \\
\text { paragraph of the introduction to note comprehensive } \\
\text { asset management is about simultaneously using a } \\
\text { firm's human resources and financial resources to } \\
\text { achieve property-level investment goals. It is our } \\
\text { hope that this brief definition adequately sets the } \\
\text { stage for the discussion that follows. }\end{array}$ \\
\hline $\begin{array}{l}\text { Information that is missing in relation to the } \\
\text { respondents (in the methodology section), is in } \\
\text { relation to the spread of participants including } \\
\text { geographical and portfolio sizes. }\end{array}$ & $\begin{array}{l}\text { P. } 8 \text { of the manuscript now notes that the firms } \\
\text { included in the sample work on behalf of owners of } \\
\text { regional, national, or international real estate } \\
\text { portfolios ranging in size from a few hundred million } \\
\text { dollars to several billion dollars. Some portfolios are } \\
\text { comprised of a single real estate product type and } \\
\text { others multiple product types. }\end{array}$ \\
\hline $\begin{array}{l}\text { The questionnaire is explained as to style of } \\
\text { questions, however could be expanded to include the } \\
\text { rational for the type of questions asked. }\end{array}$ & $\begin{array}{l}\text { Thanks to referee for making this suggestion. P. } 9 \text { of } \\
\text { the manuscript now notes that questions about the } \\
\text { differences between portfolio management, asset } \\
\text { management, and property management served as a } \\
\text { means of encouraging interviewees to discuss asset } \\
\text { management within the context of overarching } \\
\text { management hierarchies, which was essential to } \\
\text { evaluate the pervasiveness of intra-organizational } \\
\text { tensions and conflicts of interest. The manuscript } \\
\text { also notes that questions about inefficiencies in } \\
\text { existing asset management processes and barriers to } \\
\text { process improvement were used in the interviews to } \\
\text { assess whether knowledge gaps and organizational } \\
\text { inertia were perceived to be problems, and to } \\
\text { examine how any such problems affect asset } \\
\text { management practices and decision-making. }\end{array}$ \\
\hline $\begin{array}{l}\text { The author focuses on increased income as the means } \\
\text { for increasing the asset returns, however this can also } \\
\text { be obtained through reducing costs which is not } \\
\text { covered, but is also not the main focus of the paper. }\end{array}$ & $\begin{array}{l}\text { P. } 14 \text { of the manuscript now explicitly notes that } \\
\text { pushing rents and controlling expenses are both } \\
\text { means of creating value. }\end{array}$ \\
\hline $\begin{array}{l}\text { Reference is made in the results section, to 'many } \\
\text { responses'. It would be preferable to see the } \\
\text { percentage of responses. The use of the word Many, } \\
\text { is vague. }\end{array}$ & $\begin{array}{l}\text { References made to "many interviewees" and "a } \\
\text { significant number of interviewees" were removed } \\
\text { from pp. } 10,12 \text {, and } 16 \text { and replaced with } \\
\text { percentages or numbers of interviewees expressing a } \\
\text { given opinion. }\end{array}$ \\
\hline
\end{tabular}




\begin{tabular}{|c|c|}
\hline Page 1 row 21 spelling error & $\begin{array}{l}\text { We could not identify the spelling error of interest } \\
\text { and it was not caught by MS Word, but we will be } \\
\text { more than happy to address it once pointed out. }\end{array}$ \\
\hline Page 4 row 30 sentence & $\begin{array}{l}\text { The sentence was revised for clarity and now notes } \\
\text { that analytical asset managers rely heavily on key } \\
\text { performance indicators and other metrics when } \\
\text { making decisions. }\end{array}$ \\
\hline \multicolumn{2}{|c|}{ Referee 2} \\
\hline The theoretical contribution should be enlightened. & $\begin{array}{l}\text { Many thanks to the referee for encouraging us to } \\
\text { ground the work more squarely in theories of the } \\
\text { firm. This suggestion helped us more clearly } \\
\text { articulate the theoretical contribution of the } \\
\text { manuscript and link knowledge gaps, organizational } \\
\text { inertia, and conflicts of interest together in a more } \\
\text { compelling way. The abstract and introduction now } \\
\text { note that our study is motivated by behavioural } \\
\text { theories of the firm, which are latter defined and } \\
\text { discussed in the literature review on pp. } 7-8 \text {. The } \\
\text { conclusion was also revised to note that there are } \\
\text { many opportunities to apply behavioural theories of } \\
\text { the firm to the study of real estate firms - a } \\
\text { promising line of research. }\end{array}$ \\
\hline $\begin{array}{l}\text { I suggest taking into consideration the following } \\
\text { literature: Hayness and Nunnington (2010); Sceffer, } \\
\text { Singer, and Van Meerwijk (2006); Lindholm, Gibler, } \\
\text { and Levainen (2006); Wojewnik-Filipkowska and } \\
\text { Rymarzak (2013). }\end{array}$ & $\begin{array}{l}\text { Thanks to the referee for identifying these sources. } \\
\text { All of the articles were incorporated into the } \\
\text { literature review on p. } 3 \text { to highlight the extensive } \\
\text { amount of research that has been done on corporate } \\
\text { and municipal real estate asset management and the } \\
\text { relative dearth of research that has been done on } \\
\text { asset management as it pertains to properties held } \\
\text { solely for investment purposes. }\end{array}$ \\
\hline $\begin{array}{l}\text { The argumentation is built on real estate literature } \\
\text { but I suggest mentioning the general theories as done } \\
\text { by Kask (2013). Or at least adding a reference. }\end{array}$ & $\begin{array}{l}\text { Kask's (2013) work was included in the } \\
\text { aforementioned discussion of corporate and } \\
\text { municipal real estate asset management. However, } \\
\text { the theoretical frameworks summarized in the } \\
\text { dissertation were not incorporated into this } \\
\text { manuscript because they focus primary on municipal } \\
\text { real estate asset management. We alternatively } \\
\text { framed our manuscript in theories of the firm, as } \\
\text { suggested by the referee, focusing specifically on } \\
\text { behavioural theories introduced by Cyert and March } \\
\text { (1963) and expanded upon by many others. }\end{array}$ \\
\hline $\begin{array}{l}\text { I suggest adding some information as there is no } \\
\text { information when the companies were interviewed. }\end{array}$ & $\begin{array}{l}\text { P. } 9 \text { of the manuscript now notes that the interviews } \\
\text { were conducted in } 2016 \text {, with some research } \\
\text { participants contacted in } 2017 \text { and } 2018 \text { with follow- } \\
\text { up questions. }\end{array}$ \\
\hline $\begin{array}{l}\text { About the findings section presented in the abstract, I } \\
\text { suggest changing the phase "hypothesized" as it } \\
\text { suggests quantitative analysis. }\end{array}$ & $\begin{array}{l}\text { The abstract was revised to remove the word } \\
\text { "hypothesized." }\end{array}$ \\
\hline $\begin{array}{l}\text { Page } 10 \text {, line } 39-\text { I guess there is a problem in the } \\
\text { line. }\end{array}$ & $\begin{array}{l}\text { The manuscript was revised to state "A final } \\
\text { knowledge gap relates to uncertainty as to how firms } \\
\text { should train asset managers." }\end{array}$ \\
\hline
\end{tabular}


The conclusion should link back to the literature review.
The conclusion now notes that the observed obstacles to comprehensive asset management illustrate the value that can be derived from using behavioural theories of the firm to examine the decision-making processes and operating procedures of large real estate investment management firms. It also notes that this is a promising line of research likely to complement the work of other real estate scholars interested in helping such firms develop effective asset management strategies. These statements are linked back to the literature review with appropriate citations. 